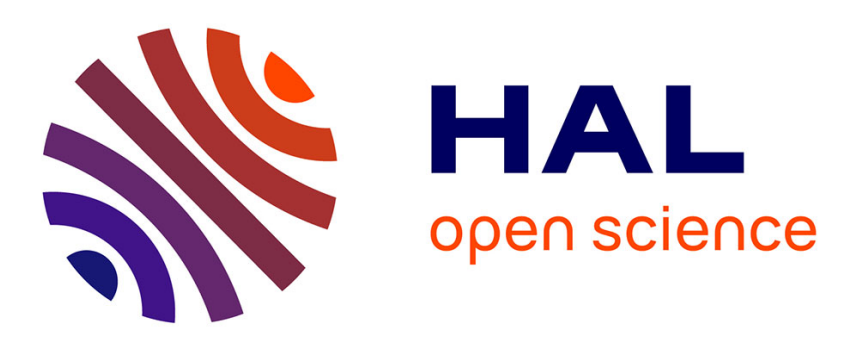

\title{
The knowledge business and the neo-managerialisation of research and academia in France
}

Gilles Pinson

\section{To cite this version:}

Gilles Pinson. The knowledge business and the neo-managerialisation of research and academia in France. Allen, Chris; Imrie, Rob. The knowledge business: the commodification of urban and housing research, Ashgate, pp.197-217, 2010. halshs-00542639

\section{HAL Id: halshs-00542639 \\ https://shs.hal.science/halshs-00542639}

Submitted on 16 Dec 2010

HAL is a multi-disciplinary open access archive for the deposit and dissemination of scientific research documents, whether they are published or not. The documents may come from teaching and research institutions in France or abroad, or from public or private research centers.
L'archive ouverte pluridisciplinaire HAL, est destinée au dépôt et à la diffusion de documents scientifiques de niveau recherche, publiés ou non, émanant des établissements d'enseignement et de recherche français ou étrangers, des laboratoires publics ou privés. 


\title{
The Knowledge Business and the Neo-Managerialisation of Research and Academia in France
}

\author{
Gilles Pinson
}

\begin{abstract}
What we need is to thatcherise France - Franck Tapiro (Nicolas Sarkozy's spin doctor, 31 January 2007).

Is research only a matter of resources and posts? So how do you explain that, with a higher research budget than Great Britain and nearly $15 \%$ more titular researchers than our English friends, France lags behind them in terms of scientific production? You'll have to explain it to me! More titular researchers, less publications and ... sorry, I don't want to be unpleasant ... but with a comparable budget, a French researcher publishes 30 to 50\% less than his British counterpart - Nicolas Sarkozy (speech about the national strategy on research and innovation, 22 January 2009).
\end{abstract}

The greatest favour that can be done to sociology is probably to prevent from asking it anything - Pierre Bourdieu (inaugural lesson, Collège de France, 23 April 1982).

\section{Introduction}

French people like to see their country as the last bulwark against the tyranny of neoliberalism. They think their country does well to resist the tide of commodification induced by globalisation and the domination of Anglo-Saxon market-friendly visions of the world. The higher education and research system is seen as an essential feature of this 'French exception'. Higher education is free in France and anybody in possession of a 'baccalauréat' can have access to it. Research is conducted inside large public research institutions populated with researchers enjoying a civil servant status. Research is supposed to be one of the key missions of the 'Colbertist State' (Mustar and Larédo 2002), a form of state intervention considered to be in the public interest.

This conception and organisation of the higher education and research system is now under serious threat. Since the election of Nicolas Sarkozy as president in 2007, the right-wing government has made the reform of the system in accordance with neoliberal and neo-managerial precepts one of its priorities. The explicit 
objectives of the reform are the adaptation of the university and research system to the needs of the so-called 'Knowledge society', the reduction of the autonomy of the academic community and the bureaucratic steering of higher education and research activities. This trend is not new. We will see that a decisive turn has been taken in the late 1990s when the left-wing government discretely decided to introduce new principles, such as a closer link between public research and higher education on the one hand, and business on the other hand. French actors have also played a key role in the 'Bologna process' that is guiding the transformation of the European system of research and higher education in line with the precepts set and diffused by institutions such as the World Bank, the IMF and UNESCO. What is new with Sarkozy is that for the first time in France a government publicly assumes a neoliberal and neo-managerial orientation of the reforms, and those reforms attack the heart of the system - universities and the government funded research organisation, the Centre National de la Recherche Scientifique (CNRS) - while creating new institutions to overcome the obstacles imposed by the existing ones.

In writing this analysis, a decision has been made not to separate the evolution and reforms of the higher education and research systems, since both are inextricably linked and targeted by the same reforms. The first part of the chapter consists of a presentation of the French system of research and higher education. This preliminary section is essential since the historical forms of organisation of the academic system shaped its evolution and the reforms that targeted it. We will see that one of the peculiarities of the French situation is the precocity and recurrence of State interventions to adapt the system to its proper needs. But for a long time, those interventions consisted in adding layers to the existing system rather than attacking its core principles and organisations. In the second part, we will see that it is precisely this peculiarity that has been questioned from the mid-1990s onwards. Until this period, policy-makers and politicians never really questioned the autonomy of academia and its corporatist forms of self-governance. What is new with the ideology of the 'knowledge economy' is that it paradoxically drove the government to attack those almost millenary principles. In the last part, we will try to identify how those reforms may change the academic ethos and practices. For this, experience will be drawn from one year spent in British academia, where experimentation in neoliberal and neo-managerial reforms have predated those in France.

\section{A Brief History of the French Research System}

Even if supranational institutions tend to have an increasing influence on the way national academia and research systems are evolving, it would be a mistake to downplay the national specificities of research systems. As Shinn puts it, 'denationalisation does not eclipse the national component of the organisation and funding devices of research and universities' (2002: 29). In this field as in others, it is important to take into account inertia and path dependence. As far as 
relationships between research and universities, on the one hand, and State, civil societies and economic interests on the other hand are concerned, the notion of 'national innovation systems' forged by Richard Nelson (Nelson 1993), is still very helpful.

The French national innovation system has been historically characterised by two main features: first, the congenital weakness of the institutions that elsewhere embody research and scholarship: the universities; second, the strong and recurrent intervention of the central State to reorganise the research and higher education system. This intervention was justified by the weakness of the universities but also tended to worsen it. This importance of the role played by the State drove Mustar and Laredo (2002) to define the French innovation system as 'Colbertist'.

\section{Strong State, Weak Universities}

The will to reorganise and to orientate scientific research is not only a recent habit of the French central State. It actually occurred much earlier in France due to two French peculiarities: the weakness of universities and the early rise of an interventionist State. The weakness of the universities became a French peculiarity under the 'Ancient Regime' (Musselin 2001). French universities fell quite early under the control of the Catholic Church and became places which reproduced an official knowledge rather than being cradles of the scientific spirit (Charle and Verger 2007). French Universities were specialised in the education of specialists - mainly lawyers, theologians and physicians- and their activities were submitted to the censorship of the Church and the State. But the centralising and reinforcing French State soon started to see in the conservative and bigoted stance of the universities an obstacle to its power and influence and started to create or to promote the development of scholar institutions released from the corset of scholastic and ecclesiastic orthodoxy. In 1530, Francis I created the 'Collège Royal' - then 'Collège de France', home of Michel Foucault and Pierre Bourdieuwhere Greek and Hebrew were taught while they were prohibited in Sorbonne. The seventeenth century, the Enlightenment century, saw the generalisation of this model. Thus while the Universities were resistant to the development of the scientific approaches, the central State sponsored them. Royal academies were created often by the recognition and funding of the activities of scholar societies. These academies enjoyed privileges and franchises that enabled them to overcome censorship. With the parlours and scholars societies, they became the cradles of the modern secular scientific culture.

After being seen as obstacles to the development of sciences and techniques by the Monarchy, the Universities were seen as remains of the Ancient Regime by the Revolutionaries. They were consequently dismantled. The Consulate and the First Empire (1799-1815) recreated them but placed them under the strict control of the central State. Napoleon I also launched a process that then proved very harmful for the universities. Eager to develop engineering and applied research in order to backup the national military forces and economic development, he 
created engineering schools, the most famous and prestigious one being the Ecole Polytechnique, that provided the basis of the development of the system of the 'Grandes écoles'. This system is formed of very selective higher education institutions operating in fields that were neglected by universities (engineering sciences, agronomics, business and commerce, public administration), that escape their control and that still provide most of the French professional and political elites. Again under the Second Empire, in 1868, faced with the underdevelopment of empirical and experimental research in France compared to what was happening in the USA, UK and Germany, the regime decided to create the Ecole Pratique des Hautes Etudes which was designed to fund research and train a new type of professor fit for the modern scientific approach. The EPHE became one of the cradles for the development of modern social sciences in France.

The Third Republic (1875-1940) tried to give power back to universities by authorising the recreation of faculties outside of Paris and releasing the central control on their functioning. However, the harm was already done. Many resources were drained towards the Grandes Ecoles and other State sponsored institutions. Most scientific research was conducted there and oriented in order to correspond with the needs of the State. The activities of the new faculties were still limited to the fields on which the Universities had a monopoly, i.e. law and medicine, where activities were oriented towards the transmission of techniques rather than towards research.

It is the very incapacity of universities, due to a lack of financial and human resources, to develop research activities that eventually led the French State to create the CNRS in 1939. The objective was to reunify in a single body all the State-controlled fundamental and applied research centres in order to coordinate the national research effort. The CNRS has three main missions: firstly, to fund the current functioning of the laboratories; secondly to fund research projects through calls and bids; and thirdly, to manage its own research staff (26,000 researchers, engineers and technicians in 2004). Unexpectedly in the French context, the major part in the governance of the new institution is entrusted to the researchers themselves. Indeed, they have the responsibility to orientate the research effort according to what is considered as strategic by the scientific community itself. Somehow, the CNRS created a realm of academic liberties that never really existed in the French universities. CNRS researchers benefit from a civil servant status and a life-time job contract, are entrusted with a mission to develop fundamental research within an institution that preserves their autonomy, and play a key role in its governance.

Nevertheless, the creation of the CNRS did not mean that the State had abandoned any will to control and orientate research activities and had given priority to fundamental research. After WWII, as well as the CNRS, the State created a series of applied research agencies in strategic sectors. The Centre National d'Etudes des Télécommunications (CNET) was founded in 1944, the Commissariat à l'Energie Atomique (CEA) in 1945, the Institut National de Recherche Agronomique (INRA) in 1946, the Centre National d'Etudes Spatiales (CNES) in 1961, the Institut National de la Santé et la Recherche Médicale (INSERM) in 1964, etc. The most 
prestigious of those établissements publics scientifiques et techniques (EPST) are usually well connected to the French State apparatus. The staffs of ministries and research institutions were usually recruited in the same pond of the Grandes Ecoles, which created a strong proximity. This proximity is attested by the budget they can count on. For instance, while in 2004 the global budget of the CNRS was made $€ 0.5$ billion, the CEA could rely on more than $€ 3$ billion.

The landscape of the French system of research evolved again in the late 1960s due to a first stage of democratisation in the higher education system. The economic development and the rise of the French Welfare State created a call for a more educated workforce. That challenge was taken up by the universities in which new departments of social sciences, sciences and economy were created or reinforced. That democratisation also provoked a significant growth of the academic staff. Universities were emerging as the main staff pool of researchers. That new situation led to the narrowing of universities and CNRS. In 1966, the CNRS decided to create some unités associées [associated units] to sponsor the research departments created in various universities. Those departments hosted researchers that were both CNRS and university staff. They were linked to the CNRS by a contract that guaranteed them, besides more scientific credibility, funds for administration, equipment and research operations. This narrowing of CNRS and universities was particularly important for the social sciences that were able to strengthen their fragile position.

Nevertheless, the coming together of those two institutions did not favour them in the long term. In the eyes of the preachers of academic reforms, they were seen to embody the weak pole of the French system of innovation. The CNRS represents the autonomy of the scientific community and the orientation towards fundamental research. The Universities have been accused of making no effort to adapt their teaching to the needs of the job markets and to solve the problem of youth unemployment. Thus, so as to orientate research towards 'social needs', a bureaucratic crusade began in the 1960s.

\section{The Early Development of Contract Research and its Unexpected Effects}

Very early on, the way the CNRS had been conceived - as an institution dedicated to fundamental research, with its own permanent research staff, and governed by the research community itself - appeared as an anomaly to the bureaucratic and political elite. As far as this elite was concerned, the research effort had to be orientated according to the social and economic needs of the nation. In the 1970s, political pressures compelled the CNRS to reorganise. Industrial demand for innovation support led the agency to create an 'engineering sciences' department. The CNRS was asked to define a scientific strategy and it launched a new policy of calls and bids on targeted themes. The central idea was to orientate researchers to topics considered as socially useful.

Social scientists were also encouraged to pay more attention to the needs of policy-makers through the development of contractual research on the initiative of 
institutions, such as planning agencies and ministries, whose central activities were not to undertake research. As Amiot (1986) states, contractual research in social science developed with the rise of the Etat planificateur, the planning State, through the 1950s and 1960s. What we call the Etat planificateur is both a whole set of institutions of agencies and a new way to govern the country. The conviction of its proponents was that modern governance should be based on a solid scientific knowledge, that the State should be endowed with an efficient apparatus able to produce statistics, to conduct economic studies, and to elaborate long term plans (Bourdieu and Boltanski 1976; Fourquet 1980). The Fourth Republic (1946-1958) saw the creation of a national planning agency (the Commissariat Général au Plan), a national agency for statistics (INSEE), and bureaus of statistics and economic studies inside key ministries like the Ministry of Finance. Faced with universities that were unable to provide the kind of economic expertise they needed, a set of schools and research centres was also created outside of the universities and CNRS. The French research system in economics was thus progressively organised by the planning networks of the central state and orientated according to its specific needs.

The installation of the 5th Republic in 1958 was an opportunity for the planners and bureaucrats to enlarge their grip on the State apparatus. The restoration of a strong executive power dedicated to the development of the country and the weakening of Parliament was a boon for the planners who had acquired key positions in the government and ministries. Under the new regime, a new device was created in order to orientate the research effort of the country. An interministerial committee for scientific research was created whose mission was to coordinate the way each department was managing its research funds. Besides its coordination mission, it is entrusted with its own funds, the National Fund for Research, which was to give a real boost to contract research (Amiot 1986). This committee was backed by the Direction Générale de la Recherche Scientifique et Technique (DGRST), a bureau located inside the Ministry of Finances.

The new role of governmental agencies in the coordination of research continued, with a renewed interest in the social sciences (Bezes 2005; 2009). In the mid-1960s, after having reorganised research in economics, the main concern of the members of the planning apparatus was about the social acceptability of economic change and the identification of non-material needs in society. They then turned themselves towards the social sciences, in the hope that they would help to build the conditions for the social acceptability of the planned change. The planners and bureaucrats 'were asking sociologists to trace for them the limit of the bearable' (Amiot 1986: 79). Their aim was also to reorganise research in the social sciences on the model that they had applied to economics: large research centres oriented to answer to bureaucratic requests (Pollak 1976). They failed. Most sociologists were reluctant to become planners' auxiliaries. However, despite this initial failure, the DGRST and the different ministries launched new calls for research specifically targeted towards social scientists. The idea was explicitly to avoid the transfer of research monies through CNRS and to establish 
direct relations with research centres in order to drive them towards more applied research. As was now common in France, 'academic institutions have not been dispossessed of their powers; but other powers and other funding sources had been set up, that were not entrusted to them and which objective was to transform the functioning of academic institutions' from outside (Amiot 1986: 87).

The development of contract research opened a period of material opulence for social sciences. Public monies were pouring into departments as never before. Although the CNRS and universities recurrent funds only covered the operating costs of research, funds from government and the ministries were large enough to support ambitious large-scale empirical research programs. Classics in French sociology like Bourdieu and Darbel's L'amour de l'art (1969), Crozier's La société bloquée (1971), or Touraine's works on post-industrial social movements were drafted from empirical research undertaken under contract to DGRST and research support units in the ministries. French urban sociology was one of the sub-disciplines in the social sciences that secured the greatest benefits from the channelling of governmental funds towards research. Indeed, it took great advantage of the creation, in 1966, of the Ministère de l'Equipement; a huge department with functions in the spheres of public works, infrastructures, housing and planning. A bureau for urban research was created inside the ministry that started to allocate large amounts of money to research teams working on the effects of urban planning on populations. With the May 1968 outburst, the funds channelled towards urban research grew even further, reaching 15 million francs per year at the beginning of the 1970s. A large number of sociologists that started their careers in the 1960s and 1970s were thus oriented to work on urban issues.

Unexpectedly, this abundance of contract funds supported research studies that gave birth to the most radical theories French urban sociology has ever produced. Castells and Godard's Monopolville (1974), a book based on research conducted between 1971 and 1973 in Dunkirk (a city drastically re-organised by State planners in order to host a large steel industry compound by-the-sea), is probably the best example of the kind of radical theories that contract research funds helped to generate. In this book, inspired by the Althusser's theory of the Capitalisme Monopolistique d'Etat, the authors tried to demonstrate how a new kind of city controlled by large industrial companies was emerging with the help of State planning. Dunkirk had been chosen by one of the largest French companies, and by the Commissariat Général au Plan within the framework of the 6th Plan (1971-1975) to host a new steel production site. However, at the same time, State offcials were eager to demonstrate their desire to solve the socio-spatial contradictions generated by economic growth. Thus the newly created Ministère de l'Equipement was entrusted with the formulation and implementation of spatial policies (planning, housing, transport) that would accompany the construction of the industrial site. Yet the authors argued this new state concern with housing conditions was little more than an exercise in ideological mystification. Production remained the priority, so the official concern for collective consumption (e.g. housing) originated from a desire to provide a support infrastructure for the production process. 
In a nutshell, Monopolville set out to analyse the extension of exploitation from the sphere of production to the sphere of the collective consumption of commodities and housing - with the state playing an orchestrating role in both processes for the purposes of maximising opportunities for capitalist profit making. Most other research studies conducted in this period displayed a similar critical stance towards the meaning, ideology and methods of State planning (Chamborédon and Lemaire 1970; Lojkine 1974; Topalov 1974; Mehl 1975; Huet et al. 1977). This being the case, it is difficult to understand why the State and, in particular, the Ministère de l'Equipement, continued to finance research of this nature but one thing is clear: the trauma among political and administrative elites generated by May 1968, and the fact that many of the staff that were hired by the bureau for urban research had a social sciences background, made them sympathetic to this kind of research. After 1981, the victory of the Left at the Presidential election enabled them to stay inside the ministries and to continue funding critical research.

Nevertheless, this kind of urban research never fully satisfied the bureaucratic elites who commissioned them. Although bureaucratic elites expected social scientists to share their intellectual interests and concerns, they encountered a social scientific community that was constantly trying to challenge their world views and to reformulate the research issues in different ways. For bureaucrats and planners who had been mainly trained in Grandes Ecoles to apply solutions rather than to undertake research, and whose vision of science was structured by what they knew about 'exact' research, it was a source of frustration. This frustration might partly explain the subsequent evolution of the State/social sciences relationships.

In this first part I tried to demonstrate that the state's interest in research is not new in France. Indeed, attempts to reorganise the research and academic system according to its own 'knowledge needs' are one of the historic peculiarities of the French State. But what should be noticed is that those attempts almost always resulted in the creation of new institutions, or new funding devices, rather than the internal reorganisation of the existing system. As Amiot put it clearly $(1986,72)$ :

The conservatism of the medieval universities led to the creation of the College de France designed to host the new disciplines rejected by universities. Later, the Académies [...] were juxtaposed next to existing institutions to host the disciplines that did not find any place either inside universities or in Collège de France. That sequence ended with the French Revolution that put down the Ancient Regime edifice and designed a brand new one. The history of the academic institutions during the 19th and 20th century offer analogue sequences: on the margins of universities, unable to innovate, the Ecole pratique des hautes études was designed under the Second Empire to develop scientific research. The creation of the CNRS testified of the insufficiency of the previous arrangements and the necessity to add another layer.

And so on, until the very last period. 


\section{Managerial Assaults on the French Research System}

The period spanning the mid 1970s to the mid 1990s did not bring about much change in the relations between social sciences and the State. The economic crisis generated cuts in Ministries' research budgets but the state planners that were in charge of these funds remained active and cultivated their networks. In compensation, the Left-wing government elected in 1981 integrated many of the researchers that were employed on contracts within the CNRS with a civil servant status. This was a period of consolidation for the French system of research and higher education. In 1984, a decree improved the status of the 'enseignantschercheurs' (i.e. professors and lecturers working within the universities) by setting up standardised salary grids and teaching duties. However, from the mid-1990s onwards, things began to change. The French polity became more sympathetic to the neoliberal narrative on higher education and research promoted by supranational institutions such as OECD and EU. This narrative was being relayed by domestic actors like Claude Allègre, a renowned geochemist and Minister of Education of the Socialist Prime Minister Lionel Jospin between 1997 and 2000. During this period, a series of silent reforms were implemented that led the French system of innovation to comply with the neoliberal Knowledge Society and New Public Management agendas. However, the election of Nicolas Sarkozy as President in 2007 has seen an intensification of these efforts to compel French academia to conform to neoliberal and NPM prescriptions.

\section{Knowledge Society and the Redefinition of the Framework of Higher Education and Research Policies}

Changes to the research environment in France cannot be understood without taking account of the global neoliberal offensive that has now targeted higher education and research institutions for more than 20 years. This offensive was launched by international institutions such as the OECD and the World Bank who have found allies within the European Commission, national governments and the business world more generally. This ideological offensive found scientific backing from new 'theories' about knowledge production which claimed that researchers' relationship with the state and business should change to comply with the reality of the knowledge economy, i.e. the links between wealth production and knowledge production. The offensive first struck in North America but has recently expanded to higher education institutions in Europe; France included (Laval 2009).

The neoliberal offensive against higher education institutions and research began in the United States in the 1970s. Scientific disciplines with the greatest potential for industrial application, such as biological engineering or computing, were compelled by the state to service business interests. Moreover, as businesses, university managers and academics themselves came to realise the economic potential and benefits of collaboration, a new movement in the privatisation of academic knowledge started. The procurement of patents for scientific achievements 
became a new priority for researchers, universities and businesses (Krimsky 2004; Duval and Heilbronn 2009) and thus opened the way for a widespread commodification of knowledge and universities (Harvey 1998; Warde 2001; Malissard, Gingras and Hemme 2003). In the 1980s, the fiscal stress imposed on universities by states and the federal governments created a new incentive for the commercialisation of research results and partnerships with private interests. In 1980, the Bayh-Dole Act (or Patent and Trademarks Law Amendments Act) gave universities and small businesses (that could be created by academics themselves) the right to claim property rights on inventions and scientific achievements that were generated using public research funds. For Slaughter and Leslie (1997), the Bayh-Dole Act was the symbol of the official legitimisation of an 'academic capitalism'.

What followed was the intellectual legitimation of this system of collaboration, which was provided by the increasing circulation of collaborating actors between academia, business, and policy networks. The best - and probably most influentialexample of this kind of intellectual legitimation is provided by the academic, Michael Gibbons; co-author of the New Production of Knowledge (1994) ${ }^{1}$ which proposes the 'two modes of production of knowledge' theory.

According to Gibbons, Mode 1 forms of knowledge production prevailed until the 1950s and were characterised by the distance that existed between the scientific world and society. Universities and academics were strictly autonomous, organised in impervious and independent disciplines, and the orientation of research was decided by academics themselves. Interactions between academia and industry were almost non existent. On the contrary, Gibbons argues that Mode 2 embodies the way science works or should work in contemporary society. The idea of Mode 2 is based on the claim that the epistemological and institutional independence of scientists is an obstacle to technological innovation and economic growth. The implication of this is that the orientation of research should be decided through a process of dialogue between academics and their political and economic partners. Priority should be given to the accumulation of knowledge that is directly applicable to the needs of government and industry because they are the engines of economic growth. Moreover the governance of universities and research institutions should be revised in order to integrate these new 'stakeholders'.

For the last 20 years, international institutions have sought to articulate and mobilise these ideas through a new set of concepts - the 'Knowledge society' or 'Knowledge economy' - in order to legitimise the restructuring of higher education and research. Although initially elaborated by international institutions such as the OECD, World Bank and UNESCO (Milot2003), the idea of the knowledge economy is now being relayed by the EU through the 'Lisbon strategy'. This 'knowledge economy' narrative posits the core sectors of the contemporary economy as characterised by constant innovation and a continuous consumption of knowledge

1 Burton R. Clark (1998) can be cited as another very influential 'expert' on those matters. 
and technologies in the pursuit of the economic growth that will apparently benefit all. Higher education, research and innovation systems are thus a crucial asset because they are axiomatic to national economic competitiveness, which is why it is said that they should be reorganised in order to comply with the new challenges of the 'knowledge economy' (Delanty 2003; Lorenz 2007; Garcia 2008; Winkin 2008). What is interesting here is the way in which the American higher education and research system that has evolved over the last twenty years is presented as the example to follow. The use of this hegemonic example is accompanied by a negative campaign that denigrates universities and researchers that are still stuck to the 'Mode 1' as malfunctioning. The Mode 2 zealots constantly disseminate stigmatising representations of the inner world of the academy (De Montlibert 2008) which they represent as closed to any collaboration with the outside world and composed of researchers that lock themselves away in their 'ivory towers' whilst being protected by life-time contracts.

Compared to its American or British counterparts, the French system of higher education has taken more time to comply with the new requisites of the hegemonic 'knowledge economy' project. But since it has started to do so, its adaptation has been quick. Claude Allègre, Minister of Education under the cohabitation government of the Socialist Lionel Jospin between 1997 and 2000, was a key figure in the mobilisation and imposition of 'Knowledge Society' doctrine on the French academy. He was responsible for the Innovation and Research Act (Loi sur l'innovation et la recherche) in 1999 which sought to import the 'enterprise culture' into the French research system. This act authorised researchers to create their own enterprises in order to capitalise on the value of their discoveries. It allowed them to take up to 15 per cent of the shares in their enterprises. It also made it easier for the CNRS and the universities to establish commercial partnerships with businesses (Malissard et al. 2003; Gingras 2003; Laval 2009). Allègre also enhanced the capacity of universities to improve upon their ability to commercialise the knowledge and inventions by endowing them with commercial offices that dealt with property rights and patenting. Finally Allègre also tried to transform the CNRS into a resources agency limiting its activities to the elaboration of calls and bids, distribution of funds and evaluation, and to transfer CNRS researchers to universities, but his attempt was rebuffed by the scientific community (Charle 1999).

On the higher education front, Allègre was one of the initiators of the 'Bologna Process', a commitment signed in 1999 by the Ministries of Education of the EU, to build an integrated and competitive European space of higher education until 2010. The launching of the process occurred one year earlier, on the 25 May 1998, when Allègre invited the Ministries of Education of Germany, Italy and United Kingdom in the Sorbonne University in Paris to celebrate the 800th anniversary of Paris University. The 'Sorbonne declaration' sealed the common will of the ministries to build a 'Europe of knowledge' that would counterbalance the 'Europe of bankers'. In actual fact, the Sorbonne declaration and the 'Bologna Process' allowed the expansion of market principles from economy to research 
and higher education. Indeed, the 'Bologna process' was soon integrated in the Lisbonna Strategy formulated by the European Council in 2000 and aiming at making of Europe the most competitive and dynamic 'knowledge economy' in the world. Concretely, the process aims at harmonising the European landscape of university diplomas by generalising a 3-5-8 system (bachelor-master-PhD) and by creating a system of credits supposed to facilitate the mobility of students. But beyond these practical arrangements, many of the Bologna process critics consider that the overarching objective is to impose an instrumental vision of research and education in which universities would be academic service providers competing in a deregulated market to attract students, the best professors and researchers and to raise private funds (Neyrat 2007; Lorenz 2007; Schultheis et al. 2008; Garcia 2009). In this free integrated market, consumers would have the 'choice' to select their providers. In order to let them exert their freedom of choice in full transparency, the 'Bologna Process' also proposes to set up 'quality assurance' devices allowing assessing and rating the providers of academic services according to standardised values. Beyond this obsession for quality assurance, many critics foresee the end of values such as academic freedom, the disinterested quest for knowledge, and free access to that knowledge.

The 'Bologna Process' was actually initiated by French actors identified with the Leftwing Party. Indeed, the origin of the process can be traced back to a report written in 1998 by the top civil servant and ex-councillor of Mitterrand, Jacques Attali, on the demand of Allègre. ${ }^{2}$ Most of the orientations of Bologna were already in the report: harmonisation of the European university grade systems; the facilitation of mobility, etc. More decisive was the statement that the emergence of a globalised higher education market was urging the rationalisation of the European university systems and especially the French one characterised by a high degree of fragmentation. The report thus recommended the regrouping of forces and the identification of a limited number of 'excellence poles'. As Neyrat (2007: 148) put it, 'from now on, it is the position of France in the world market of higher education that seems to be the ultimate justification of reforms'. That new orientation constitutes a break with the previous philosophy of higher education policy that was aiming mainly at facilitating access to higher education and was - officially - based on a principle of equal treatment of the different institutions. 'Performance, not the maintenance of [territorial or social] balances, has become the principle of equity: what is equitable is to reward the best and not necessarily to share out resources on identical bases' (Musselin 2009: 79).

The second half of the 1990s was a crucial period in which many of the principles that would inspire the reforms of the subsequent period were laid down. The hegemonic project of 'knowledge society/economy' and the narrative about the necessary commodification of higher education and research started to structure discourses and practices of French policy-makers. The influence of international

2 Pour un modèle européen d'enseignement supérieur, Report of the Commission chaired by Jacques Attali, published on 5 May 1998. 
organisations (OECD, World Bank, UNESCO, and the European Round Table lobby) and the mythical example of the American academic and research system played a key role in the process but one should not underestimate the role of French bureaucrats and politicians to import and spread those new principles.

\section{The New Governance of Universities and Research}

After 2000 a new period opened for a more systematic implementation of most of the Knowledge Economy and New Public Management recipes. Those recipes are, roughly speaking: the reduction of the autonomy of the academic community; the limitation of internal corporatist regulations; the reinforcement of bureaucratic control and political steering of universities; research institutions founded on the belief that scientific 'discoveries' can be programmed; the introduction of stakeholders (businesses, consumers) in the governance of academic institutions; constant evaluation and the elaboration of performance measurement instruments; and the development of an entrepreneurial culture among the academic communities through bids, contracts and project management. What Lorenz calls a 'managerial colonization' (2007: 49) of the public service of higher education and research was enforced in France by a series of laws, some of which had academia as a specific target, whereas others were part of broader reforms of the French State that had an impact on the management of universities and research institutions.

Within the latter type of reforms, it is worth mentioning the much commented on 2001 'LOLF' (Loi organique relative aux lois de finances) passed under the Jospin government (Bezes 2009). At first sight, this Act aims at reorganising the ways that State funds are allocated, managed and controlled and does not seem to be related to the governance of research and universities. But in actual fact, its implementation has revolutionised the traditional conception of public services and the way they are produced. The LOLF embodies the conversion of French State top civil servants and politicians to the New Public Management. It implies a shift from a logic of resource distribution in which funds are allocated to a department without being clearly associated to specific tasks, to a logic in which funds are allocated to specific programmes for which performance indicators are elaborated in order to ensure the efficient and effective use of funds. The bureaucratic control of funds is no longer concerned with simply the legal authority to spend but also on the economy and efficiency of spending. The LOLF is crucial because the principles it laid down have been implemented within the research and higher education policies. This focus on performance and results has allowed subsequent right-wing governments to point to poor performance in terms of student graduation and publications of French universities. In doing so, they were overlooking the fact that French universities cannot select their students and have thus been in the front line to absorb successive waves of higher education massification while the resources they have been allocated have constantly remained low compared to the level of support given to the Grandes écoles system. Recently, this denigration campaign had a concrete outcome with the reform of the funding system of the 
universities. Until recently, funds were allocated by taking account of the number of students registered at the university and contracts were negotiated between the State and each university in order to take into account the socio-economic characteristics of the university public. With the new system, only the number of students succeeding at the exams and the number of publishing teachers is taken into account. Behind this new system, many critics see a political will to realise the vision of the Attali report: the rationalisation of the French university system to around eight or ten big campuses able to deliver masters and $\mathrm{PhDs}$ and the downgrading of the other to the status of 'colleges' delivering only bachelors and deprived of any research structures.

The 2006 Research and Innovation Act (Loi d'orientation et de programmation sur la recherche et l'innovation, LOPRI), passed under the right-wing government of Dominique de Villepin, made explicit the application of NPM and neoliberal principles to research and education. The ideological framework of the legislators was clearly presented in the presentation report of the law: 'In a merciless world competition, it is urgent to build up in France uncontested research champions'; 'It is about time to reinforce partnerships between public and private research', and for researchers to get involved in 'economic growth founded on knowledge'. Assuming that private research is more efficient, the law facilitates the possibility for private organisations to get public research funds and to get involved in the funding and governance of public research institutions. As decisively, the law created the Agence Nationale de la Recherche (ANR) in 2005; the new centre of the research funding device. The ANR is clearly an instrument meant to erode the model of research organisation stabilised after the WWII and embodied by the CNRS. The purpose is to replace recurrent funds granted to the CNRS and its laboratories by a device of funds distribution based on calls and projects privileging publicprivate partnerships and allowing a tighter political and bureaucratic control. The 'quest for excellence' is also present in the LOPRI through the creation of Pôles de Recherche et d'Enseignement Supérieur (PRES). These poles are supposed to be an energetic response to the first publication of the famous Shanghai ranking that initially revealed the fragmentation of the French research system. Quite simply, they are groupings of universities and schools on a territorial basis that will enable the creation of publications pools to allow them to be 'better' ranked. They can thus be interpreted as a precursor of the reorganisation of the French university systems around a dozen poles. Finally, the law also planned the creation of an evaluation agency for higher education and research (Agence d'évaluation de la recherche et de l'enseignement supérieur, AERES), that will be in charge of the application of the principles of 'quality assurance'.

The elaboration of the LOPRI and the very tense climate between the government and the scientific world led to an unprecedented social movement amongst researchers, and to the creation of Sauvons la recherche. This association brings together a wide scope of researchers working within the universities, the CNRS and other public research institutions in different disciplines. Since the row 
about the LOPRI, it has been at the forefront of the contestation of neoliberal reforms led by the successive right-wing governments.

Nevertheless, the election of Nicolas Sarkozy as President of the Republic in 2007 gave a new impetus to these reforms. The novelty with Sarkozy is that he is the first French politician endowed with an executive mandate who explicitly assumes a neo-liberal orientation together with a comprehensive programme of massive cuts in the civil service workforce and a neo-managerial reform of administration (Bezes 2009). Assuming a 'market populist' stance, he has chosen to overtly provoke the socio-professional groups that are supposed to oppose resistance to his program, including the academic community. His speech on research of the 22 January 2009 is a clear illustration of this strategy. This mendacious speech was clearly meant to discredit and isolate an incompetent and conservative academic community in order to get public support for his reforms. French researchers were described as lazy and publishing much less than their foreign counterparts. Yet in reality the rank of France in various publication tables remained more than honourable despite constant underfunding and a structural advantage for English speaking countries. Sarkozy asserted that academics are one of the rare professions escaping regular evaluation. He also claimed that his Government had made unprecedented financial efforts to support research, even though France is the only country of the OECD that had reduced its financial support to research and higher education in the years since 1995.

This speech was preceded by two governmental initiatives that had already aroused the hostility of the academic community. The first was the Act on universities' liberties and responsibilities (Loi relative aux libertés et responsabilités des universités, LRU) passed in August 2007. The aim of this new law is twofold: first, to transform universities into 'executive agencies' and second, to weaken corporatist and disciplinary regulations. In the new legal framework, universities are supposed to elaborate their own project and to identify their priorities in terms of research and curricula in close relation with their local and economic environment. For this, more power was given to the Presidents of the universities who became the real bosses of their staff; more emphasis was placed on having socio-economic partners on university councils; and universities got more power over their staff. In actual fact, the autonomy awarded is conditional. It has been granted in exchange for compliance with project management and their involvement in academic competition. Awarding autonomy to the universities is a way for the central administration to disengage from the daily management of programmes and staff, and to gain a 'hands-off' style steering capacity (Neave Van Nught 1991). 'Rather than specifying precisely what is to be done, government establish broad objectives, define several principles framing the action of universities, allocate a part of the resources allowing the achievement of objectives and intervene only $e x$ post, if evaluations reveals difficulties' (Musselin 2009: 76). In other words, distant control, the 'governance of conduct' and the control of outputs are supposed to be more efficient than direct intervention and focus on inputs. Such disciplinary power is a good means to reduce the real autonomy of the academic community. 
The last brick of the new research and academic governance device imagined by right-wing government has been put down in 2008 and created a mass opposition movement among academics and students. This brick was a decree project elaborated by the Sarkozy's minister of higher education and research, Valérie Pécresse, allowing the presidents of universities to modulate the teaching duty of the academics according to criteria such as research performances, involvement in administrative and political functions, etc. Seen as a new step in the promotion of NPM principles and in the rise of a presidential arbitrary power, the decree project was confronted with huge dissent that compelled the minister to redraft it. Based on a desire to save public funds, the decree project was rooted in the assumption that academic workforce is not efficient and should be 'remobilised' - a typical assumption of the neo-managerial thought. For academics, the flaw of the decree is its tendency to consider the teaching task as a punishment. But more than anything the decree and Sarkozy's speech were seen as public disavowal from their employer that added to the 'market populism' that tends to describe professions whose activity cannot be assessed on simple market criteria as useless and privileged. During the first semester of 2009, the biggest academic social movement since 1968 paralysed most French universities.

\section{Excavating the Future of French Academia in the Anglo World}

This last section is dedicated to the exploration of the potential effects of the neomanagerial reforms on research and academic practices. It has been developed from two sources: first, texts that provide an analysis of the evolution of academic practices in the Anglo-American world where the effects of those reforms are already visible; second, a work experience in a British research centre on urban issues located in the Manchester region. I will call it the SKI centre. The SKI centre is a particularly good example of the mutation of British urban research since its activities were in response to 'calls for research proposals' by government and industry. This was necessary because SKI relied on contractual funds to survive, and because most of its members had abandoned teaching activities to dedicate themselves to contract research.

\section{Commodification of Research and Mercantile Manners}

A defining characteristic of the Anglo-American research system is contract research. The first problem with this is that increases in contract research funding justify the reduction of public funding to universities; the second problem is that the augmentation of the share of contractual research is at the expense of recurrent funding of research organisations. This reduction of recurrent funding compels researchers to orientate their research towards responses to an external demand rather than what is considered important by the scientific community. This might sound good to economic interests, politicians and bureaucrats but it is well-known 
from the history of science that research, 'discoveries' and applications, cannot be planned with a linear perspective. As Foellmi (2007) put it: 'No theory of relativity, no GPS'. Einstein's discoveries were essential to the eventual birth of the GPS, but it could not have been invented if Einstein had oriented his research towards this aim. The way science works is totally incompatible with planning or any obligation to respond in priority to corporate or societal needs. Market or bureaucratic steering of research activities usually diverts researchers from essential scientific discussion. The SKI centre was created with a faith in the capacity of researchers both to respond to external demands and to remain active in scientific debate. It proved impossible to do both.

Even more worrying is the phenomenon of 'academic affairism' that developed mostly in the physical and natural sciences, with the development of universitybusiness research partnerships. Krimsky (2004) describes how the development of such business partnerships has led to the transformation of the academic ethos and, in particular, the development of worrying habits. The most worrying one is the trend to adjust research results to the interests of the funding entity. For instance, Stelfox et al. (cited in Duval and Heilbron 2006) have showed that the nature of the judgement of pharmaceutical researchers can be associated with the existence or absence of financial links with the firms producing drugs. In the social sciences, academics with similar links that have reached a large public audience do not hesitate to cash in on their interventions in seminars or conventions, or as consultants for government and thinks tanks. In France, the fact that academic salaries have not been increased for some time has created incentives for them to create consulting agencies thus enabling them to cash in on extra activities, sometimes at the expense of their scientific activities.

Criticism of 'academic affairism' and the greedy behaviour that it encourages should not be seen merely as a moral issue but one that drives to the heart of what academia is about: the interest in 'disinterestedness'. The specificity of scientific activities is that they are driven by 'specific libido and beliefs, irreducible to the sole greed for material gain' (Duval and Heilbron 2006: 9). The accumulation of scientific knowledge is guaranteed by the specificity of the scientific field. In this field, values like truth and commitment to objectivity have more power than anywhere else. Social hierarchy is determined by the judgment of peers and this judgement is based on the evaluation of the researcher's achievements in the quest for truth rather than public success or financial success. As Bourdieu (1994) has put it, researchers have an 'interest in disinterestedness' and that is what makes them contribute to scientific accumulation. Thus, as Krimsky reminds us (2004), scientific accumulation is closely dependent on the maintenance of a strong morale of public interest which is itself guaranteed by institutional arrangements such as substantial and recurrent public funding of research and civil servant status for researchers. On the contrary, the development of private funding, public-private partnerships and the priority put on contractual research and project management has brought about the alteration of academic values. As Stengers (2004) explained, those phenomena tend to transform the way researchers define their own interest. 
Such researchers shift from a situation in which their interest is to seek recognition from their peers to a situation in which they seek recognition and rewards from industry, in which the priority is to say something that the industry will consider as 'bankable'.

\section{Academic Individualism}

The other effects that neoliberal and neo-managerial rationalisation of higher education and research have brought about are: first, the degradation of the feeling of professional collective belonging among researchers; second, the development of a strong academic individualism.

One of the first signs of academic individualism appeared in the AngloAmerican world as an aftermath of the rush to patents and licenses opened by the laws facilitating the claiming of property rights on scientific innovations. That trend created numerous conflicts in the academic world, conflicts that are increasingly solved in courts. At the end of the day, far from being a fuel for innovation, the generalisation of patenting practices creates obstacles to the circulation of scientific information. More generally, what was one of the foundations of the academic community, i.e. the free circulation of knowledge and its status of collective property, is now at risk (Lawrence 2008; Chamayou 2009). Even if patenting is a very marginal practice in social sciences, the climate of competition that has been imposed in departments and research centres due to publication tables, constant evaluation and individualised job contracts, will probably have the same effects on collaboration between academics. While working in the SKI centre, I was struck by the fact that competition rather than collaboration and fraternal relationships was the rule between academics, especially the youngest ones that had been socialised under the rubric of the Blairite university.

Paradoxically, while the enforcement of neo-managerial principles aims at making the agents more faithful to their employer and their behaviour more predictable and conforming to what is expected from them, it often has the opposite effect. The best examples might be the effect that publication tables, constant evaluation, individualised job contracts and new forms of work organisation have had on the ethos of British academics and their relations to academic institutions. As Faucher-King and Le Galès (2007: 82) writing on the Blairite 'bureaucratic revolution' put it,

... the multiplication of audits erodes the trust in professional ethics and the sense of public service. Such a social control contradicts the idea that everybody is acting in a moral way and laminates the trust in social competence. Within organisations, one of the consequences of the audit procedures is the degradation of the employees' morale and the decline of morality.

Where neo-managerialism has been implemented, it has engendered a propensity amongst academics to use its devices to pursue their individual interests rather 
than the interests of their institution or science. NPM has a kind of 'performative power'; it creates what it describes. The cynical and calculating rational choice actor, who lies at the heart of NPM conceptions is actually produced by NPM rather than pre-existing it. But $\mathrm{s} /$ he often acts at the expense of the institution $\mathrm{s} /$ he should be accountable to. Thus British academics that have been subjected to audits and compelled to fill time sheets and to act as entrepreneurs tend now to focus on their career and on the increase in their market value rather than on scientific achievements and the welfare of their organisation. This drives them to avoid non-productive activities such as teaching, to recycle data, to write several articles on the basis of minimal empirical work, and to offer their services to the better endowed universities at the expense of making a durable investment in a department or some other collective research endeavour. While in SKI centre, I was struck to meet professors with absolutely no teaching experience. I was astonished by the incredible turn-over of staff and by the fact that the research centre was a collection of individuals whose pursuit of their own enhanced marketability overrode any desire to join a collective of people that shared a passion for the same object or the same theoretical inclinations.

The fact that the increase of controls engenders attempts to overcome controls is also visible in research centres in Britain. This can be seen in the spatial organisation of office space in some British universities with the emergence of panopticons (open plan offices etc.) that enable a permanent surveillance of the academic workforce. But far from being efficient, such open-offices engender a plethora of escaping strategies such as multiplying tea-breaks whilst endeavouring to inform colleagues about how busy one is. This is at the expense of contributing to a collective work of knowledge accumulation.

Another effect of the rise of academic individualism is the erosion of academia as a community. As some historians have reminded us (Charle and Verger 2007) universities were historically created as self-organised corporations of masters and students strongly bonded together to defend a common ideal: the production of knowledge as an end in itself (Caillé and Chanial 2009). The unity of those strange corporations was also linked to the strong peculiarity of their activities, that is, what Bourdieu called skholè (1997), which can be translated by 'leisure'. If academic activities can be compared to leisure it is because in the European university tradition they are ontologically disconnected from any form of social, religious, political or economic utility or necessity. This disconnection allows academics to maintain a distance from the world and to have access to pure knowledge. That is why accountability to 'external agents' is a notion that is barely compatible with university and research and why academia is such a strange world for the rest of society, especially to politicians and bureaucrats for whom accountability is a key concern. The other peculiarity of academic work is that it is composed of a set of activities (reading, observing, contemplating, discussing, writing, etc.) whose common points are that they are difficult to quantify and organise and that are difficult to separate from the private lives of those that undertake them. 
Indeed, the scholastic lifestyle implies a certain embeddedness of professional activities into the private and social life of the academic. Academics live with their tools and products and therefore socialise with the people of the academic corporation. More than for any other profession, their jobs are a matter of personal identity construction as much as a means to making a living. The peculiarity of this academic life (autarchic, contemplative and liberated from utilitarian imperatives) is one of things that cements academics into communities whilst also being the guarantee of their ability to produce valuable knowledge. Yet, nowadays, neomanagerial reforms are tearing this life apart. Whilst in the SKI centre, I was appalled by the inexistence of academic sociability, by the strict separation that researchers were building between their professional and personal lives, and by the fact that the researchers' work had no real prolongation in their personal life. This disembeddedness of scholarship from researchers' personal lives, which has been generated by the NPM ethos, has weakened the academic community's capacity to defend itself and has thereby reinforced the trend towards academic individualism, free riding behaviours, and the lack of loyalty to the academic community and its institutions.

In spite of its numerous flaws, the research and higher education systems existing under Mode 1 that were based on civil servant job contracts, standardised salary grids, academic autonomy, and internal regulation were not that inefficient at all. Indeed they were miraculously efficient compared to their actual cost! Their efficiency was linked to the fact that they could rely on a workforce that was faithfully committed to its public service. This workforce was more motivated by its collective sense of purpose, shared inside strong academic communities, rather than by individual rewards. The reforms described in this chapter are destroying this collective sense of common purpose and the dedication of academics to systems of service provision that are not based on profitability but on an ideal of disinterestedness and universal access to knowledge. In an article in which he tries to give sense to the 2009 academics movement resorting to the Lafontaine fable The wolf and the dog, D'Iribarne (2009) compares academics to wolves that made the choice of a miserable but free life. For him, the fact that French academics are actually doing their job while they are poorly paid constitutes a miraculous propensity to dedication that the Sarkozy reforms are contributing to dissolve.

The material situation of university professors is pitiful. Even compared to the standards of high public service (I don't even mention the private sector), their pay slip, bonus included, is ridiculous. No way for them to have a decent office, a business car or even a secretary. They fly in economy class. But they are free. They conceive their courses as they wish; do the research they find interesting. And if some of them (mostly researchers) do not do much, the very fact that they are not sanctioned is the living proof that those who, in large majority, are working hard are doing so on their own free will, without anything constraining them. 
That miraculous unconstrained dedication might be the next victim of neomanagerial reforms. And free wolves might turn into cheating dogs.

\section{Conclusion}

What is at stake nowadays is the survival of university and scientific research. Indeed the paradox of the so-called 'Knowledge society' is that its advent could also signal the death of university and scientific research. That is exactly what Michael Gibbons had in mind while citing this Douglas Hague's sentence in a report on 'Higher Education in the 21st century' for the World Bank: 'If universities do not adapt, we will do without them'. This is exactly what Sarkozy's government had in mind when refusing to seriously negotiate with the academic and student movements in the first half of 2009.

The most worrying thing is the absolute ignorance of the same élites who proclaim their belief in the 'knowledge society'. Most of them have been trained in Grandes Ecoles and have absolutely no experience of research. Their dominant vision of science is a vision where scientific progress is linear, where applications can be clearly foreseen, and thus where research can be planned according to application objectives. The idea of an academic world funded by the State but enjoying a large autonomy is thus unbearable.

The challenge for academics now is to defend principles and organisational arrangements that have become almost unbearable in public opinion and among policy-makers' networks which have been converted to 'market populism'. Those principles embodied in organisations are the same that Veblen (1919) tried to defend at the beginning of the twentieth century while observing the intrusion of businessmen and bureaucrats in the management of universities. He argued that the missions of university and scientific research were incompatible with any commercial imperatives and with any form of hierarchical management. Scientific progress cannot bear any form of commercial or bureaucratic control and hierarchies. That is what makes academics so insufferably ungovernable but that is the price that must be paid. The function of criticism through the delivery of "non consensual expertise' (Krimsky 2004: 121) is the ultimate vocation of universities which should not bear any form of constraint. It is even more important to defend this principle because, with the increasing dominance of the global media within everyday life, universities are now one of the last places where non consensual expertise can be expressed. 